\title{
Kudoa dianae sp. n. (Myxosporea: Multivalvulida), a new parasite of bullseye puffer, Sphoeroides annulatus (Tetraodontiformes: Tetraodontidae)
}

\author{
Iva Dyková ${ }^{1}$, Emma Josefina Fajer Avila ${ }^{2}$ and Ivan Fiala ${ }^{3}$ \\ ${ }^{1}$ Institute of Parasitology, Academy of Sciences of the Czech Republic, Branišovská 31, 37005 České Budějovice, Czech \\ Republic; \\ ${ }^{2}$ Centro de Investigación en Alimentación y Desarollo, A.C. Unidad de Investigación en Acuicultura y Manejo Ambiental del \\ CIAD, A.C. Av. Sábalo Cerritos s/a, Estero del Yugo, Mazatlán, Sinaloa, Mexico; \\ ${ }^{3}$ Faculty of Biological Sciences, University of South Bohemia, Branišovská 31, 37005 České Budějovice, Czech Republic
}

Key words: Myxosporea, Multivalvulida, taxonomy, SSU rDNA

\begin{abstract}
A new multivalvulid myxosporean species, Kudoa dianae sp. n., is described from bullseye puffer, Sphoeroides annulatus (Jenyns) (Tetraodontiformes: Tetraodontidae). Plasmodia develop in extramuscular sites, in the wall of oesophagus and less frequently on mesenteries. Mature spores can reach lumen of the digestive tract directly by disruption of plasmodial wall or via macrophage transport to the oesophageal epithelium. New species is characterised by morphology of spores and by the complete sequence of SSU rRNA gene that differs from all hitherto known sequences of Kudoa species. Spore morphology (moderate-sized, simple non-ornate spores, quadrate in apical view) clusters with that of Kudoa scienae, K. cerebralis, K. chilkaensis, K. leiostomi, K. funduli, K. cascasia and K. ovivora. Analysis of phylogenetic relationships (using SSU rRNA gene sequences) among five Kudoa species, the molecular data of which are available thus far, revealed that $K$. dianae is distinguishable from these five species and that its closest relation is with $K$. miniauriculata.
\end{abstract}

The list of named species of the genus Kudoa Meglitsch, 1947 (with 44 items in Moran et al. 1999 and 45 in Swearer and Robertson 1999) expanded recently to $47, K$. camarguensis and $K$. ramsayi being the last newly described species (Pampoulie et al. 1999, Kalavati et al. 2000).

Regarding the type of tissue infected, muscleinfecting species (35) predominate. Other species have been found in extramuscular localisations, e.g., gills, brain, kidney, gallbladder, and ovaries (Swearer and Robertson 1999). Of the muscle-infecting species, the agents of post-mortem myoliquefaction (K. thyrsites, $K$. paniformis and $K$. miniauriculata), have been frequently studied and papers describing their biology, impact of infections on the aquaculture industry and commercial fisheries and diagnostic methods have been published (Egusa and Nakajima 1980, Kabata and Whitaker 1981, Patashnik et al. 1982, Langdon et al. 1992, Whitaker and Kent 1992, Moser and Kent 1994, Whitaker at al. 1996, Moran et al. 1999). Species infecting smooth muscles, e.g., K. ciliatae, K. intestinalis, K. sphyraeni, K. valamugili (Maeno et al. 1993, Dyková et al. 1994, Swearer and Robertson 1999) were found to develop mostly in the wall of digestive tract. Multiple sites of infection in the same host specimen were recorded rather exceptionally, e.g., in Kudoa thyrsites infection in Coryphaena hippurus, Kudoa sp. infection in Morone americana (Swearer and Robertson 1999) and Kudoa sp. infection in cultured Sparus aurata (Paperna 1982).

Using cluster analysis of the dissimilarity coefficients, Swearer and Robertson (1999) defined, among 45 Kudoa species included in their study, 7 groupings with unique combinations of taxonomic characters. Different patterns of similarity were discovered by Hervio et al. (1997). They compared SSU rDNA sequences of four Kudoa species, analysed their phylogenetic relationships and concluded, curiously enough, that Kudoa species cluster by geographic location rather than by morphology of spores. This statement is a big challenge to use both morphological and molecular approach in identifying Kudoa species. As several papers (Paperna 1982, Langdon 1990, Lom et al. 1992, Maeno et al. 1993, Swearer and Robertson 1999) evidenced, Kudoa spp. developing in uncommon sites or unusual types of tissues deserve attention even when their impact on the host is not dramatic. We believe that the study of extramuscularly developing Kudoa species can help to better understand the biology of this group of myxosporeans. Below we describe a new species of the genus Kudoa Meglitsch, 1947 from the bullseye puffer, Sphoeroides annulatus (Jenyns) (Tetraodontidae), a fish species native to the coast of Pacific state of Sinaloa (Mexico). The cultivation potential of this fish is currently being estimated (Duncan and Rodríguez 2001). 


\section{MATERIALS AND METHODS}

In total 150 bullseye puffers, Sphoeroides annulatus (Jenyns, 1842) were collected along the Pacific Coast, in Bahía de La Paz, BCS, and off the coast of Mazatlán, Sinaloa, Mexico. Thirty-seven juvenile specimens were 17.2 (10.5$22.0) \mathrm{cm}$ in length and their weight was $104.2(40-204) \mathrm{g}$. Specimens (in total 113) of adult-age group were 28.3 (20.5$39.4) \mathrm{cm}$ in length and their weight was $527.9(250-1450) \mathrm{g}$.

The body cavity of fish was opened from the anal orifice to the gills and buccal cavity and the internal organs were examined. A macroscopic inspection of organs was followed by examination of fresh mounts of tissue pieces about $3 \mathrm{~mm}$ in diameter, compressed between the slide and coverslip. Several samples from each organ and from different parts of body musculature were examined. Samples of all organs and somatic muscles were routinely fixed with Davidson fixative and processed for histology using Paraplast as the embedding medium and haematoxylin and eosin (H\&E) and Giemsa solutions for staining.

The lesions that contained Kudoa spores were fixed also for transmission electron microscopy (in 3\% glutaraldehyde buffered with sodium cacodylate), stored for 3 weeks in holding sodium cacodylate buffer and postfixed with $1 \%$ buffered osmium tetroxide. After dehydration in an acetone gradient series, the tissues were embedded in Spurr's resin. The ultrathin sections were stained with uranyl acetate and lead citrate and observed in a JEOL JEM 1010 electron microscope.

Spores collected from fresh material were fixed in $80 \%$ ethanol (EM grade) and submitted to SSU rRNA gene sequence analysis. Approximately 100 spores stored in ethanol were centrifuged and washed two times in PBS. Three freezethaw cycles were performed in order to release the contents of spores. DNA was extracted with DNeasy Tissue Kit (Qiagen) according to manufacturer's protocol and resuspended in a final step in $200 \mu 1 \mathrm{H}_{2} \mathrm{O}$. The almost entire SSU rRNA gene was amplified using forward primer 5'-GGTCATATGCTC GTCTCAAA-3' and reverse primer 5'-TACAAAGGGCAGA GAC-3' designed out of alignment of four Kudoa species studied by Hervio et al (1997): Kudoa paniformis (AF034640), K. miniauriculata (AF034639), K. amamiensis (AF034638) and $K$. thyrsites (AF031413). PCR reactions were performed in total volume of $25 \mu 1$ containing PCR buffer (TaKaRa), $2 \mathrm{mM}$ of $\mathrm{MgCl}_{2}, 0.2 \mathrm{mM}$ of dNTPs, 1 unit of Taq DNA polymerase (TaKaRa) and $25 \mathrm{pmol}$ of each primer in a T3 Thermocycler (Biometra). Denaturation at $95^{\circ} \mathrm{C}$ for $3 \mathrm{~min}$ was followed by 35 cycles consisting of $94^{\circ} \mathrm{C}$ for $1 \mathrm{~min}, 53^{\circ} \mathrm{C}$ for $1 \mathrm{~min}$ and $72^{\circ} \mathrm{C}$ for $2 \mathrm{~min}$ and ended by 10 min extension at $72^{\circ} \mathrm{C}$. PCR products were cloned into $\mathrm{pCR} \AA 2.1 \mathrm{TOPO}$ Cloning vector using the TOPO-TA Cloning Kit (Invitrogen) and sequenced on an automatic sequencer $\mathrm{CEQ}^{\mathrm{TM}} 2000$ (Beckman Coulter) using CEQ DTCS Dye Kit (Beckman Coulter) according to the manufacturer's protocol. The almost entire SSU rRNA gene sequences were aligned using MegAlign version 4.00 (DNASTAR package) with ClustalW algorithm. Genetic distances were calculated using the Kimura 2-parameter algorithm (Kimura 1980) out of alignment with excluded gaps. Ambiguous regions, incomplete sequences, invariant sites and gaps were removed (1618 characters), and remaining 580 variable sites were used for phylogenetic analysis. Phylogenetic trees were constructed using maximum parsimony, neighbour-joining and maximum likelihood methods in the frame of PAUP program (Swofford 1998). The robustness of the tree was tested by bootstrap analysis with 1000 replicates.

\section{RESULTS}

Spores with all characteristics of the genus Kudoa Meglitsch, 1947 were found in macroscopical lesions localised in two sites: in the wall of oesophagus, and on mesenteries. White cystic formations (plasmodial stages) and white or yellowish formations with less defined borders (masses of spores originated from plasmodia) were easily detectable through the mucosa epithelium when oesophagus was cut open. Such lesions were found in $7(19 \%)$ out of 37 juvenile specimens of Sphoeroides annulatus and in $22(20 \%)$ out of 113 adult specimens. Less frequent were lesions localised on mesenteries (prevalence $5.4 \%$ in juveniles and $7.9 \%$ in adult specimens). Lesions localised in both sites were found in $24 \%$ of juveniles and $34 \%$ of adult specimens examined.

\section{Description}

In apical view mature spores (Fig. 1) were quadrate with rounded edges. Four polar capsules were equalsized, pyriform, $2.0 \mu \mathrm{m}$ in length and $1.5 \mu \mathrm{m}$ in width. The two turns of the polar filament were not clearly seen in fresh spores, but were counted in electron micrographs (Figs. 12, 13). The length of spores measured in lateral view was $5(4.5-5.5) \mu \mathrm{m}$, the width as well as thickness was $6(5.5-6.5) \mu \mathrm{m}$. The shape of spores was very simple in both apical and lateral views, the posterior part of spores was rounded, suture lines were only slightly indicated in fresh spores. Shell valves were thickened in the apical, slightly protruding part of spore (Figs. 1, 12).

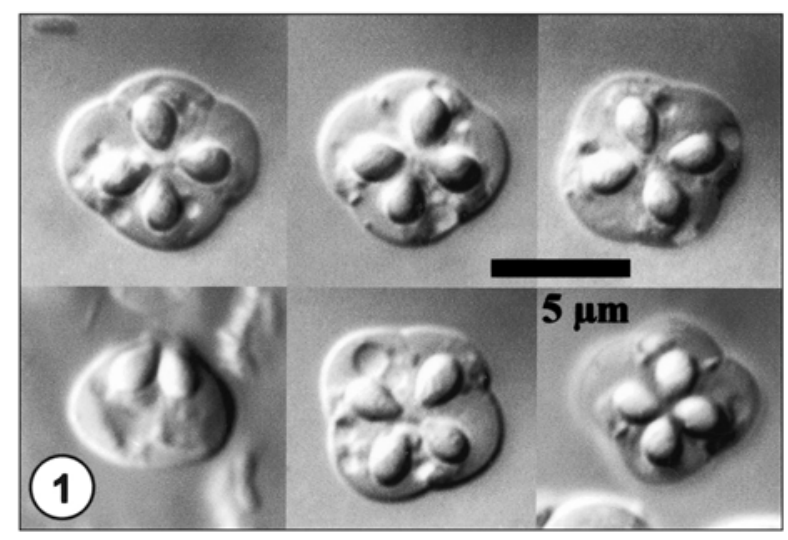

Fig. 1. Spores of Kudoa dianae sp. n. in apical and lateral views. Nomarski differential interference contrast. 


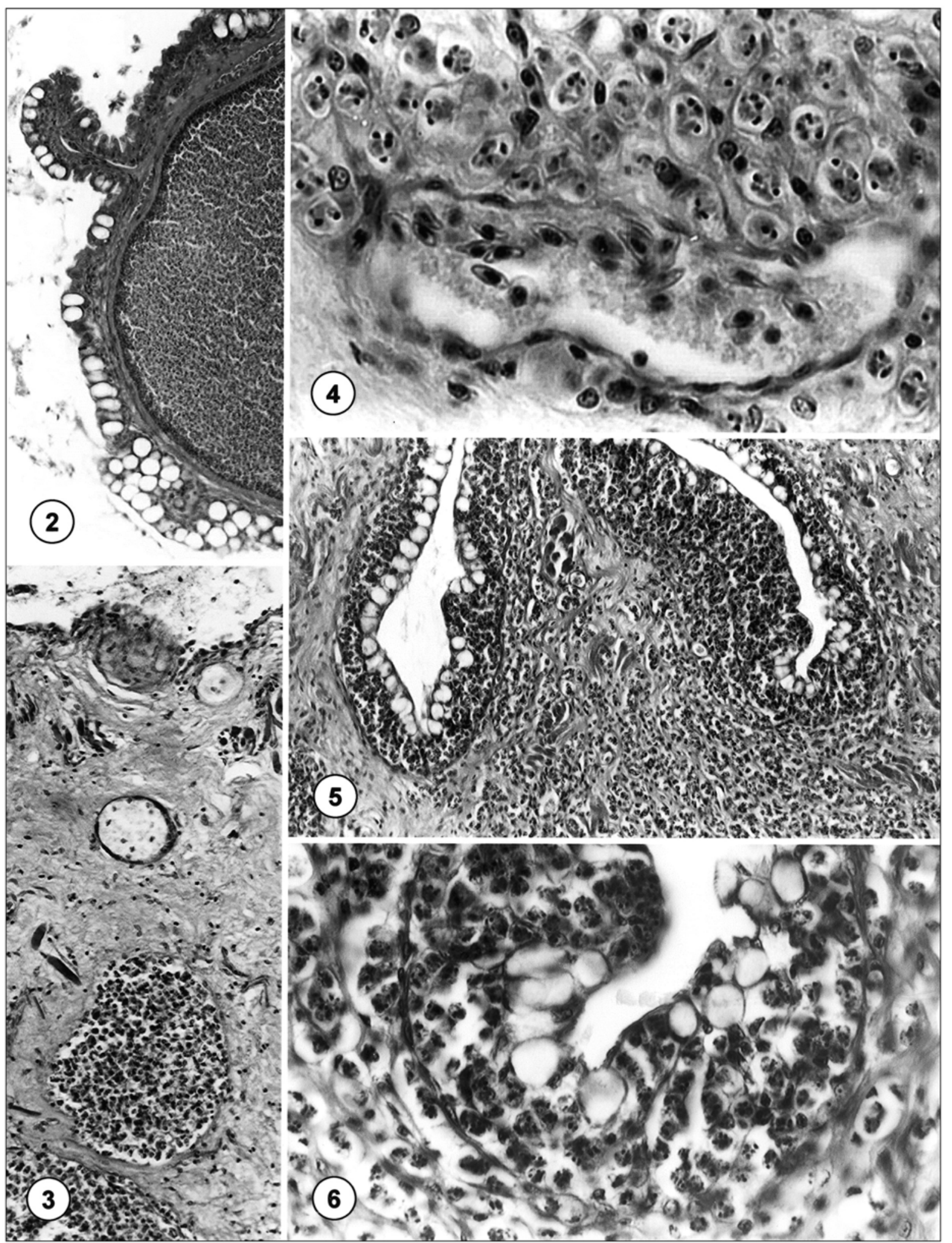

Figs. 2-6. Histology of Kudoa dianae infection in Sphoeroides annulatus. H\&E. Fig. 2. Part of plasmodium localised under the epithelium of oesophagus, $\times 210$. Fig. 3. Agglomeration of spores in the connective tissue of oesophageal wall. Note the desquamation of mucosa epithelium (top), $\times 250$. Fig. 4. Mature spores surrounding in huge amounts the blood vessel in oesophagus, $\times 860$. Figs. 5, 6. Substitution of epithelial layer of oesophagus with mature spores transported via macrophages, $\times 240$ and $\times 840$ respectively. 


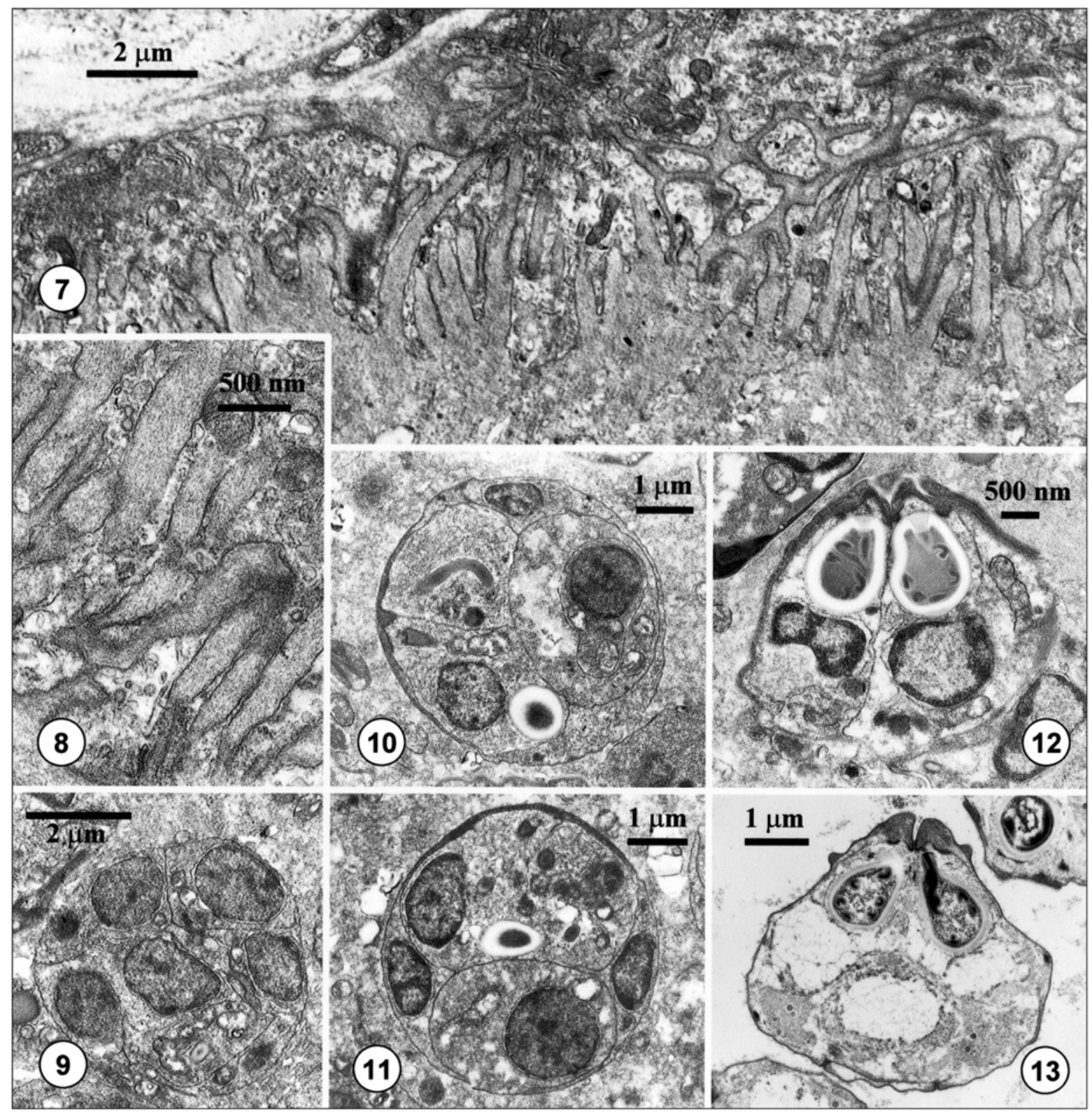

Figs. 7, 8. Kudoa dianae infection in Sphoeroides annulatus: host-parasite interface with numerous projections on the periphery of plasmodial stage. Transmission electron micrographs. Figs. 9-13. Development of Kudoa dianae. Transmission electron micrographs. Fig. 9. Sporoblast in the early phase of differentiation. Fig. 10. Capsulogenesis. Fig. 11. Capsulogenesis and sporogenesis. Figs. 12, 13. Mature spores.

In the process of sporogenesis (Figs. 9-11), the sporoplasm complex represented by one cell enveloping the other (Fig. 10) and a lack of pansporoblast formation were observed. Numerous, sometimes interconnected projections on the periphery of plasmodial stages (Figs. 7,8 ) characterised the host-parasite interface. They reminded to some extent of rich folding of plasmalemma in Kudoa shkae (Dyková et al. 1994).

Polysporous plasmodia filled with mature spores were white, spherical or ovoid formations with a maximum diameter of $5.0 \mathrm{~mm}$. Histological examina- tion of oesophageal lesions revealed that plasmodia developed in subepithelial connective tissue, lamina mucosa and among muscle fibres of oesophageal wall.

\section{Molecular data}

The amplified and sequenced SSU rRNA gene region of this Kudoa species was $1568 \mathrm{nt}$ in length including regions corresponding to forward (20nt) and reverse (16nt) primers. The $\mathrm{G}+\mathrm{C}$ content of the sequenced gene was $46.17 \%$. The sequence was deposited in the GenBank under accession number AF 414692. The SSU rRNA gene of this Kudoa species from S. annulatus 


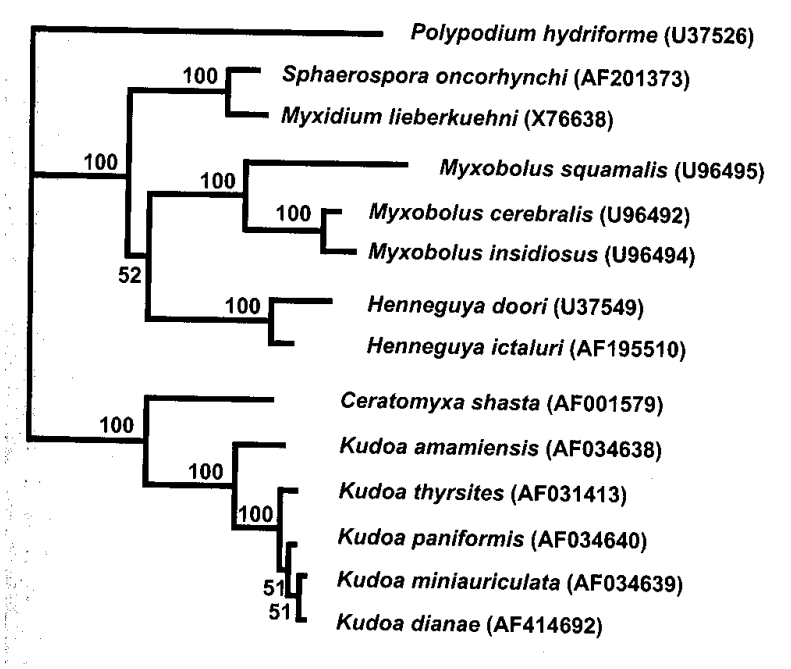

Fig. 14. Maximum likelihood phylogenetic tree (-ln $\mathrm{L}=5203.10902)$ constructed out of 580 variable sites of SSU rRNA gene sequences. Bootstrap values (1000 replicates) are included. The GenBank accession numbers corresponding to sequences of individual species are in the parentheses.

revealed $98.8 \%$ sequence identity with $K$. miniauriculata, $98.4 \%$ with $K$. paniformis, $97.7 \%$ with $K$. thyrsites and $92.8 \%$ with $K$. amamiensis. Dissimilarity values ranged from 1.2\% (Kudoa sp. from $S$. annulatus vs. $K$. miniauriculata) to $7.2 \%$ (Kudoa sp. from $S$. annulatus vs. K. amamiensis). The similarity between Ceratomyxa shasta and Kudoa spp. was 84.0-84.9\% whereas identities between Kudoa spp. and other myxozoan species ranged from 67.1 to $75.5 \%$. The trees constructed using maximum likelihood (Fig. 14), maximum parsimony and neighbour-joining methods (not shown here) revealed the same topology. All SSU rRNA gene sequences from Kudoa spp. clustered within a monophyletic group.

\section{Taxonomic affinities}

The simple non-ornate morphology of Kudoa spores from $S$. annulatus closely resembles spores of the species of cluster $F$ as defined by Swearer and Robertson (1999), but except for the shape of spores and polysporous type of plasmodial stages it shares no other feature with the seven species assigned to cluster F. Since this Kudoa species from $S$. annulatus is, to our knowledge, the first species of the cluster F defined also by a complete sequence of SSU rRNA gene that differs from all hitherto known sequences of Kudoa spp., we decided to establish this species as a new one and name it Kudoa dianae sp. $\mathrm{n}$.

Taxonomic summary - Kudoa dianae $\mathrm{sp} . \mathrm{n}$.

T y p e h o s t : Sphoeroides annulatus (Jenyns, 1842) (Tetraodontiformes: Tetraodontidae).

T y p e lo c a li ty: Pacific Ocean, Bahía de La Paz, BCS, and off the coast of Mazatlán, Sinaloa, Mexico.

$\mathrm{S}$ i t e s of i n f e c t i o n : Oesophagus - subepithelial connective tissue; mesentery.
P r e v a 1 e n c e : $24 \%$ in juveniles, $34 \%$ in adult specimens.

E t y m o log y: The specific name was derived from the host common name as used in Spain (botete diana).

D e p o s it i o n of mate ria $1 \mathrm{~s}$ : The complete SSU rRNA gene sequence was deposited in GenBank under Acc. No. AF414692. The slides with the syntypes have been deposited in Centro de Investigación en Alimentación y Desarollo, A.C., Unidad de Investigación en Acuicultura y Manejo Ambiental del CIAD, A.C. Mazatlán, Sinaloa, Mexico and in the Institute of Parasitology, Academy of Sciences of the Czech Republic, České Budějovice, Czech Republic, Coll. No. H-PM 065-069.

\section{Host reaction}

Plasmodial stages found in tissue samples examined histologically were fully developed, containing only mature spores (Fig. 2). No signs of inflammatory reaction were detected in this stage of infection. In the same sites where plasmodial stages completed their development and in surrounding tissues, agglomerations of spores lacking demarcation by plasmodial wall were also found (Fig. 3). When liberated from plasmodia, spores were present in huge amounts in the subepithelial layer of connective tissue and accumulated around blood vessels (Fig. 4). They also immigrated via macrophages into the epithelial layer and substituted it in many places (Figs. 5, 6). The host tissue response manifested by encapsulation of spores by connective tissue, was observed exceptionally, in two samples only.

\section{DISCUSSION}

The importance of an accurate identification of myxosporean species infecting wild, commercially unimportant fishes was mostly related with the source of infection for cultured fishes. In Sphoeroides annulatus, which is a candidate for additional production by fish culture, the exact inventory of parasites is extremely important. Until Hervio et al. (1997) brought new insight into the taxonomy of Kudoa species, our observations indicated that species identification was optimal if based on both light and transmission electron microscopy (Dyková et al. 1994). Unfortunately, ultrastructural characters were studied in only a few currently described species. Due to the paucity of ultrastructural data the present clustering of Kudoa species based on light microscopical morphology of spores may be too simplified. Molecular taxonomy of the genus Kudoa is in its infancy. The necessity to include more Kudoa "isolates" in rDNA studies has already been stressed by Hervio et al. (1997) for $K$. thyrsites, a species reported until now from many fish species. Langdon et al. (1992) expanded the host range of $K$. thyrsites to 20 species belonging to 10 families. Similarly, $K$. nova also was reported to have a wide host range (Kovaleva et al. 1979). In the morphological cluster F (sensu Swearer and Robertson 1999), characterised with moderate-sized quadrate spores with apical valve extensions and equal-sized pyriform polar 
capsules, Kudoa dianae is the first species for which the SSU rDNA sequence of nucleotides was determined. The cluster is heterogeneous and probably artificial: while it contains four species described from striated muscles ( $K$. scienae, $K$. chilkaensis, $K$. leiostomi, $K$. funduli), other species were reported from extramuscular sites ( $K$. cerebralis in brain, $K$. ovivora in ovaries and $K$. cascasia on mesenteries). The hosts of this group of Kudoa species are most diverse marine, brackish and freshwater fishes belonging to eight families (five of the order Perciformes, one each of the orders Beloniformes, Cyprinodontiformes and Tetraodontiformes). The geographic origin of the fish hosts (the Pacific, Atlantic and Indian Oceans) is also diverse.

The current dataset of Kudoa spp. characterised with morphological and molecular methods is limited, and can hardly change the concept of classification. Complete nucleotide sequences of SSU rDNA from a wide range of morphologically defined species are needed to recognise distinct patterns, establish the degree of differences at the molecular level that corresponds to the species level and verify whether the low host specificity claimed for some species of the genus Kudoa is real. Low bootstrap values in the phylogenetic tree suggest that in addition to the use of rRNA gene sequences some other molecular approaches might be of use in the future.

Since the life cycle of no Kudoa species is known, we only can speculate on the transmission of infections. If an invertebrate host is considered, the route by which spores reach the aquatic environment is crucial. The comparatively high prevalence of above $20 \%$ of $K$. dianae infection in the very specific sites and with the very low intensity can only be secured by a regular rather than incidental route of spore liberation to the aquatic environment. While in Kudoa ciliatae infection located in the lamina muscularis of the intestinal wall of Sillago ciliata, the enteral dissemination of infection was conjectured (Lom et al. 1992), in $K$. dianae it was clearly proven. In comparison to $K$. ciliatae, plasmodia of $K$. dianae develop in a closer vicinity to the lumen of oesophagus so that their "ulcerations" are more probable. In addition to this, mature spores can reach lumen of the intestine via macrophage transport.

Acknowledgements. Financial support was provided by the grant of CONACyT $36621 \mathrm{~B}$ (Mexico) and by the grant MSMAJ06/98: F1-123100003 (Czech Republic). We extend our thanks to Marcial Arellano Martínez, M.Sc., and Ing. Gabriela Aguilar Zarate for technical assistance regarding host collections.

\section{REFERENCES}

DUNCAN N.J., RODRÍGUEZ G.A. 2001: Induced spawning of the bullseye puffer Sphoeroides annulatus. Book of Abstracts. Aquaculture 2001. Lake Buena Vista, Florida, January 21-25, p. 196.

DYKOVÁ I., LOM J., OVERSTREET R. 1994: Myxosporean parasites of the genus Kudoa Meglitsch, 1947 from some Gulf of Mexico fishes: description of two new species and notes on their ultrastructure. Eur. J. Protistol. 30: 316-323.

EGUSA S., NAKAJIMA K. 1980: Kudoa amamiensis n. sp. (Myxosporea: Multivalvulida) found in cultured yellowtails and wild damselfishes from Amami-Ohshima and Okinawa, Japan. Bull. Jpn. Soc. Sci. Fish. 46: 1193-1198.

HERVIO D.M.L., KENT M.L., KHATTRA J., SAKANARI J., YOKOYAMA H. 1997: Taxonomy of Kudoa species (Myxosporea), using a small-subunit ribosomal DNA sequence. Can. J. Zool. 75: 2112-2119.

KABATA Z., WHITAKER D.J. 1981: Two species of Kudoa (Myxosporea: Multivalvulida) parasitic in the flesh of Merluccius productus (Ayres, 1855) (Pisces: Teleostei) in the Canadian Pacific. Can. J. Zool. 59: 2085-2091.

KALAVATI C., BRICKLE P., MacKENZIE K. 2000: Two new species of myxozoan parasites (Myxosporea, Multivalvulida, Bivalvulida) from fishes of the Falkland Islands. Acta Parasitol. 45: 285-288.

KIMURA M. 1980: A simple method for estimating evolutionary rates of base substitutions through comparative studies of nucleotide-sequences. J. Mol. Evol. 16: 111120.

KOVALEVA A.A., SHULMAN S.S., YAKOVLEV V.N. 1979: Myxosporidia of the genus Kudoa (Myxosporidia, Multivalvulea from the Atlantic Ocean). In: M.V. Krylov
(Ed.), Systematics and Ecology of Sporozoans and Cnidosporidia, Akademia Nauk SSSR, Leningrad, p. 4246. (In Russian.)

LANGDON J.S. 1990: Observations on new Myxobolus species and Kudoa species infecting the nervous system of Australian fishes. J. Appl. Ichthyol. 6: 107-116.

LANGDON J.S., THORNE T., FLETCHER W.J. 1992: Reservoir hosts and new clupeoid host records for the myoliquefactive myxosporean parasite Kudoa thyrsites (Gilchrist). J. Fish Dis. 15: 459-471.

LOM J., ROHDE K., DYKOVÁ I. 1992: Studies on protozoan parasites of Australian fishes. 1. New species of the genera Coccomyxa Léger et Hesse, 1907, Ortholinea Shulman, 1962 and Kudoa Meglitsch, 1942 (Myxozoa, Myxosporea). Folia Parasitol. 39: 289-306.

MAENO Y., NAGASAWA K., SORIMACHI M. 1993: Kudoa intestinalis n. sp. (Myxosporea: Multivalvulida) from the intestinal musculature of the striped mullet, Mugil cephalus, from Japan. J. Parasitol. 79: 190-192.

MORAN J.D.W., MARGOLIS L., WEBSTER J.M., KENT M.L. 1999: Development of Kudoa thyrsites (Myxozoa: Myxosporea) in net-pen reared Atlantic salmon determined by light microscopy and polymerase chain reaction test. Dis. Aquat. Org. 37: 185-193.

MOSER M., KENT M.L. 1994: Myxosporea. In J.P. Kreier (Ed.), Parasitic Protozoa. Vol. 8. Academic Press, New York, p. 265-318.

PAMPOULIE C., MARQUES A., ROSECCHI E., CRIVELLI A.J., BOUCHEREAU J.L. 1999: A new myxosporean parasite, Kudoa camarguensis n. sp., recorded on two 
goby species (Teleostei: Pisces) in the Rhône delta (Mediterranean Sea, France). J. Euk. Microbiol. 46: 304-310.

PAPERNA I. 1982: Kudoa infection in the glomeruli, mesentery and peritoneum of cultured Sparus aurata L. J. Fish Dis. 5: 539-543.

PATASHNIK M., GRONINGER H.S., BARNETT H., KUDO G., KOURY B. 1982: Pacific whiting, Merluccius productus: I. Abnormal muscle texture caused by myxosporidian-induced proteolysis. Mar. Fish. Rev. 44: 1-12.

SWEARER S.E., ROBERTSON D.R. 1999: Life history, pathology, and description of Kudoa ovivora n. sp.

Received 29 May 2001
(Myxozoa, Myxosporea): an ovarian parasite of Caribbean labroid fishes. J. Parasitol. 85: 337-353.

SWOFFORD D.U. 1998: PAUP*: Phylogenetic Analysis Using Parsimony (*and other methods). Version 4.0b4. Sinauer Associates, Sunderland, Massachusetts, USA.

WHITAKER D.J., KENT M.L. 1992: Kudoa thyrsites (Myxosporea) and soft flesh in pen-reared coho salmon. Newsl. Am. Fish. Soc. Fish Health Sect. 20: 4-5.

WHITAKER D.J., KENT M.L., SAKANARI J.A. 1996: Kudoa miniauriculata n. sp. (Myxozoa, Myxosporea) from the musculature of bocaccio (Sebastes paucispinus) from California. J. Parasitol. 82: 312-315.

Accepted 27 August 2001 